\title{
Original
}

\section{Simultaneous serodetection of major rat infectious pathogens by a multiplex immunochromatographic assay}

\author{
Noriko TOSA ${ }^{1)}$, Tomoko ISHIDA ${ }^{2)}$, Kumiko YOSHIMATSU ${ }^{3)}$, Nobuhito HAYASHIMOTO ${ }^{2)}$, \\ Kanae SHIOKAWA ${ }^{4)}$, Akira TAKAKURA ${ }^{2)}$ and Jiro ARIKAWA ${ }^{4)}$ \\ 1) Institute for Animal Experimentation, Faculty of Medicine, Hokkaido University, Kita 15, Nishi 7, Kita-ku, Sapporo, \\ Hokkaido 060-8638, Japan \\ 2) ICLAS Monitoring Center, Central Institute for Experimental Animals, 3-25-12 Tonomachi, Kawasaki, Kanagawa 210-0821, \\ Japan \\ ${ }^{3)}$ Laboratory of Animal Experimentation, Institute for Genetic Medicine, Hokkaido University, Kita 15, Nishi 7, Kita-ku, \\ Sapporo, Hokkaido 060-0815, Japan \\ 4) Department of Microbiology and Immunology, Faculty of Medicine, Hokkaido University, Kita 15, Nishi 7, Kita-ku, Sapporo, \\ Hokkaido 060-8638, Japan
}

\begin{abstract}
Rapid and simple serologic tests that require only a small amount of blood without the euthanization of animals are valuable for microbial control in colonies of laboratory animals. In this study, we developed a multiplex immunochromatographic assay (ICA) for detection of antibodies to Sendai virus (also known as hemagglutinating virus of Japan), hantavirus, and sialodacryoadenitis virus, which are causative agents of major infectious diseases in rats. For this assay, an ICA strip was placed into a microtube containing $150 \mu \mathrm{l}$ PBS and either $0.75 \mu \mathrm{l}$ of rat serum or $1.5 \mu \mathrm{l}$ of whole blood. Binding antibodies were visualized by using anti-rat IgG antibody-conjugated colloidal gold. Under these conditions, the multiplex ICA simultaneously and specifically detected antibodies to multiple antigens. Positive serum samples for each infectious disease were used to evaluate the sensitivity and specificity of the multiplex ICA. The sensitivities of the multiplex ICA for Sendai virus, hantavirus, and sialodacryoadenitis virus were $100 \%, 100 \%$, and $81 \%$, respectively. No nonspecific reactions were observed in any of the 52 positive sera against heterologous antigens. In addition, 10 samples of uninfected sera did not show any bands except for the control line. These observations indicate high specificity of the multiplex ICA. Moreover, the multiplex ICA could be applied to diluted blood. These results indicate that the multiplex ICA is appropriate for rapid and simple serological testing of laboratory rats.
\end{abstract}

Key words: microbiological monitoring, multiplex immunochromatographic assay, rats, small amount of serum

\section{Introduction}

The quality of laboratory animals to be used in experimental studies must be carefully maintained, and infectious agents of laboratory animal colonies must be diligently monitored. The microbiological status of rodents has typically been monitored by exposing sentinel animals to potentially contaminated soiled bedding or exhaust air of individually ventilated cages for several weeks. ELISA and PCR/culture/microscopic examination are the main tests used for serological diagnosis of infectious diseases and detection of pathogens in laboratory rats and mice, respectively. Commercially available ELISA kits, such as MONILISA ${ }^{\mathrm{TM}}$ (Wakamoto, Tokyo, Japan), have mainly been used for in-house monitoring.

Assessment of the microbial status without euthaniz- 
ing animals, including sentinels, is now considered to be important from the viewpoint of the 3Rs. A multiplex microbead immunoassay and PCR-based detection of antigen in feces have been reported as methods for diagnosing infectious disease without euthanizing animals [1-6]. We previously reported that the use of a multiplex immunochromatographic assay (ICA) enabled simultaneous and specific detection of antibodies to mouse hepatitis virus (MHV), Sendai virus (also known hemagglutinating virus of Japan, HVJ), and Clostridium piliforme (the pathogen that causes Tyzzer disease) with small amounts of blood that can be collected without euthanizing mice [7]. Additionally, multiplex ICA is useful for in-house monitoring due to its ability to simply and rapidly detect antibodies against multiple antigens without the need for an expensive, dedicated analyzer.

We also reported that an ICA using a minute amount of rat serum is a highly sensitive, rapid, and simple diagnostic method for detecting IgG to pathogenic orthohantaviruses, which are causative agents of rodent-borne viral zoonoses, hemorrhagic fever with renal syndrome and hantavirus pulmonary syndrome $[8,9]$. The results of those studies indicate that the use of a multiplex ICA is a promising strategy for simultaneously detecting serum antibodies to various rat pathogens.

In this study, we developed and evaluated a multiplex ICA for rats that simultaneously detects serum antibodies to HVJ, Seoul type orthohantavirus (Hanta), and sialodacryoadenitis virus (SDAV).

\section{Materials and Methods}

\section{Control antigen}

Inactivated fractions of purified MHV (S strain) and HVJ (MN strain) virions were provided by the ICLAS Monitoring Center (Central Institute for Experimental Animals, Japan) for detection of IgG to SDAV and HVJ, respectively $[10,11]$. The MHV S strain antigen crossreacts with SDAV [12]. A recombinant antigen (N-terminal 103 aa of nucleocapsid (N) protein, HS103) for Hanta diagnosis was prepared as previously described $[8,9,13]$.

\section{Serum and blood}

Serum samples obtained from rats experimentally or naturally infected with SDAV or HVJ were diluted at 1:40 with ELISA buffer. Samples with ELISA OD values greater than 0.3 were considered positive for respective viruses, according to the standards of the ICLAS Monitoring Center. Sample that were positive by ELISA were confirmed by performing an immunofluorescent antibody assay [11]. The protocol for collecting positive serum samples was approved by the IACUC according to the Regulations for Animal Experimentation of the Central Institute for Experimental Animals, Japan. The regulations were established in compliance with the law for humane treatment and management of animals.

Serum samples obtained from urban rats were diluted at 1:200 with ELISA buffer. Samples with ELISA OD values greater than 0.2 were considered positive for Hanta. Samples that were positive by ELISA were confirmed via an immunofluorescent antibody assay [8]. All animal experiments were performed after obtaining permission from the IACUC of Hokkaido University.

Uninfected sera and whole blood specimens were collected from ten euthanized sentinel SD rats and one euthanized sentinel SD rat, respectively, that had been housed in the Institute for Animal Experimentation (Faculty of Medicine, Hokkaido University, Japan). The sentinel SD rats were euthanized for microbiological monitoring through inhalation of an overdose of isoflurane, in accordance with the National University Corporation Hokkaido University Regulations on Animal Experimentation, National University Corp. (Sapporo, Japan). Whole blood was obtained without the addition of anticoagulant. Husbandry and care procedures complied with the Standards Relating to the Care and Management of Laboratory Animals and Relief of Pain, Ministry of Environment of Japan, and followed recommendations in the Guide for the Care and Use of Laboratory Animals [14]. The health status of SPF animals was assessed 3 times each year for the following pathogens: Corynebacterium kutscheri, Mycoplasma pulmonis, Salmonella spp., Bordetella bronchiseptica, Streptococcus pneumoniae, Clostridium piliforme, HVJ, SDAV, Hanta, ectoparasites, intestinal protozoa, and pinworm. The sentinel rats were free of these pathogens.

\section{Multiplex ICA}

Preparation of a colloidal gold conjugate: Anti-rat IgG antibody-conjugated colloidal gold was prepared as described previously [8]. Briefly, a gold colloid solution (WRGH2, Winered Chemical, Tokyo, Japan) was mixed with an equal volume of $10 \mathrm{mM}$ Tris- $\mathrm{HCl}(\mathrm{pH} 8.15)$. Rabbit anti-rat IgG antibody (Sigma-Aldrich, St. Louis, MO, USA) was diluted to $1.5 \mathrm{mg} / \mathrm{ml}$ by using $10 \mathrm{mM}$ Tris- $\mathrm{HCl}(\mathrm{pH} \mathrm{8.15)}$ and then mixed with 2 volumes of the colloidal gold dilution in a siliconized tube. After brief sonication, the mixture was incubated for $20 \mathrm{~min}$ at room temperature, after which a $1 / 3$ volume of blocking solution comprised of $2.5 \%$ casein sodium (Wako, Osaka, Japan) in $10 \mathrm{mM}$ Tris- $\mathrm{HCl}$ (pH 9.2) was added. The mixture was sonicated briefly, incubated for $20 \mathrm{~min}$ at room temperature, and centrifuged at $14,000 \times g$ for 
$15 \mathrm{~min}$. After removal of the supernatant, the pellet was resuspended in blocking solution, bringing the volume up to the initial volume of colloidal gold. After brief sonication, the mixture was incubated for $20 \mathrm{~min}$ at room temperature and then centrifuged at $14,000 \times g$ for 15 min. Finally, the supernatant was removed, and the pellet was resuspended with $200 \mu 1$ of blocking solution.

Preparation of a conjugate pad: A glass-fiber conjugate pad (GFDX103000, MilliporeSigma, Billerica, MA, USA) was soaked in $0.5 \%$ casein in $20 \mathrm{mM}$ sodium phosphate buffer ( $\mathrm{pH} 7.8$ ) for $20 \mathrm{~min}$. The pad was washed with $3.0 \%$ sucrose in double-distilled water and air-dried overnight. The pad was coated with the prepared colloidal gold conjugate at a dose of $200 \mu 1 / 30 \mathrm{~cm}$. The pad was air-dried overnight and stored at room temperature.

Preparation of a multiplex ICA strip: HVJ, Hanta, MHV, which was used for detection of IgG to SDAV, and goat anti-rabbit IgG antibody (MP Biomedicals, Solon, $\mathrm{OH}$, USA) were diluted with $0.05 \%$ casein sodium in $10 \mathrm{mM}$ $\mathrm{PB}$ (pH 7.2) to adjust the concentrations to $0.5 \mathrm{mg} / \mathrm{ml}$ for HVJ antigens, to $1.0 \mathrm{mg} / \mathrm{ml}$ for Hanta and MHV antigens, and to $0.15 \mathrm{mg} / \mathrm{ml}$ for the IgG. These reagents were immobilized on a nitrocellulose membrane (Hi-Flow Plus $135 \mathrm{Membrane}$ Card, $60 \mathrm{~mm} \times 300 \mathrm{~mm}$, MilliporeSigma) by using a pen (Super Brush for Copic Sketch and Ciao, Too Marker Products, Tokyo, Japan) to draw thin lines for the reagents at the test line position (antigen) and control line position (anti-rabbit IgG antibody). An ICA strip containing the 3 antigens and the control as separate lines was used as a multiplex ICA strip. After the membrane had been dried at room temperature for $15 \mathrm{~min}$, it was soaked in $20 \mathrm{mM}$ sodium phosphate buffer containing $0.5 \%$ casein $(\mathrm{pH} 7.8)$ for $20 \mathrm{~min}$ to block the unsaturated area. Then the membrane was washed twice ( 5 min each time) with double-distilled water, soaked in $3.0 \%$ sucrose in double-distilled water, and air-dried overnight. Finally, a sample pad $(20 \mathrm{~mm} \times 300 \mathrm{~mm}$; Chromatography Paper, Whatman, GE Healthcare BioSciences, Pittsburgh, PA, USA), conjugate pad, nitrocellulose membrane, and absorbent pad $(50 \mathrm{~mm} \times 300 \mathrm{~mm}$; catalog no. CFSP20300, Cellulose Fiber Sample Pad Strips, MilliporeSigma) were assembled on a membrane card (MilliporeSigma). The combined membranes were cut into 2-mm-wide strips by using a paper cutter. The structure of the ICA strip is shown in Fig. 1A. The ICA strip was stored at room temperature in a dry box until use and used within 3 months.

Dilution of serum and whole blood for ICA: A $0.75-\mu \mathrm{l}$ serum sample was added to $150 \mu$ of PBS, making a 1:200 dilution. To prepare a positive serum mixture, $0.35-\mu 1$ portions of either 2 or 3 serum samples that were positive for SDAV, HVJ, and Hanta were added to 150 $\mu 1$ of PBS. In addition, to examine the effect of RBCs on the ICA, $1.5 \mu$ l of whole blood was added to the diluted serum as a control whole blood dilution, and the results were compared with those of a serum dilution.

Procedure for the ICA: An ICA strip was placed directly into a microtube containing PBS-diluted serum or whole blood (Fig. 1B). The tube was left to sit for 15 min, and then the ICA strip was examined visually. A sample that showed both test and control lines for detection of anti-rat IgG antibody was regarded as positive, and a sample that showed only the control line was regarded as negative.

\section{Results}

\section{Determination of the basic conditions for the multiplex ICA}

ICA with a single antigen (single ICA) was performed by using different concentrations of positive serum (1:50, 100, and 200) and antigens (1:1, 10, and 100). Single ICA with SDAV and Hanta antigens at a concentration of $1.0 \mathrm{mg} / \mathrm{ml}$ and HVJ antigen at a concentration of 0.5 $\mathrm{mg} / \mathrm{ml}$ detected antibodies in serum diluted 1:200 (data not shown). In addition, no nonspecific reactions were observed when serum from an uninfected rat was used under these conditions. The multiplex ICA using all 3 antigens specifically and simultaneously detected antibodies to the corresponding antigens (Fig. 2). Two antigen lines, HVJ and SDAV, HVJ and Hanta, or Hanta and SDAV, appeared in PBS with serum mixtures positive for HVJ and SDAV (Fig. 2, lane 5), HVJ and Hanta (Fig. 2, lane 6), and Hanta and SDAV (Fig. 2, lane 7), respectively. Three antigen lines, HVJ, Hanta, and SDAV, appeared in PBS containing serum mixture positive for HVJ, Hanta, and SDAV (Fig. 2, lane 8).

\section{Evaluation of the sensitivity and specificity of the multiplex ICA}

Ten, 10, and 32 samples of sera positive for antibody to HVJ, Hanta, and SDAV, respectively, were used to evaluate the sensitivity and specificity of the multiplex ICA. The multiplex ICA detected the antigen-specific antibody in all of the HVJ-positive serum samples (Fig. $3 \mathrm{~A})$ and all of the Hanta-positive serum samples (Fig. 3B). A specific antibody to SDAV was detected in 26 (81\%) of 32 SDAV-positive serum samples (Table 1). Figure $3 \mathrm{C}$ shows multiplex ICA results for 10 samples in which the specific antibody to SDAV was detected. No nonspecific reactions were observed in any of the 52 positive sera. Moreover, 10 serum samples from uninfected rats did not show any bands except for the control line (Fig. 3D). These observations indicate high specificity of the multiplex ICA. 
A

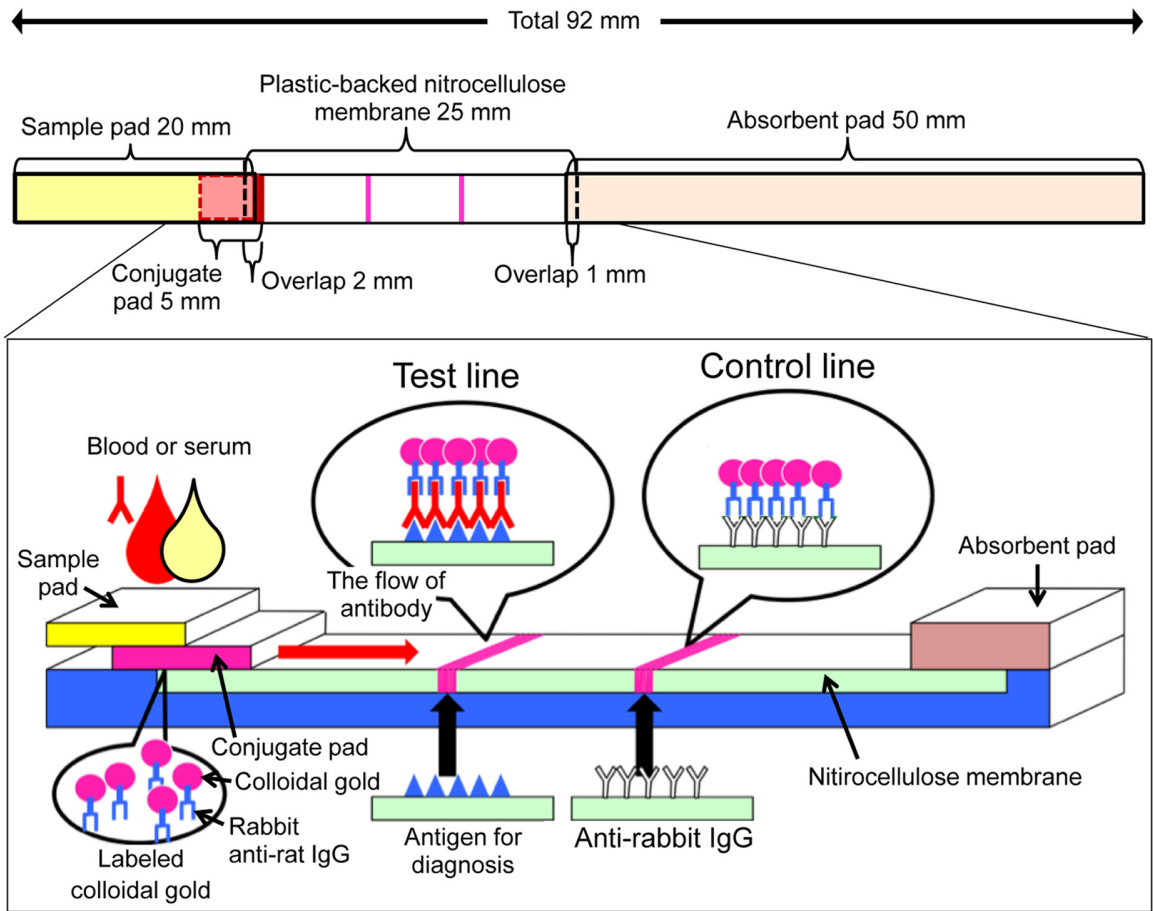

B
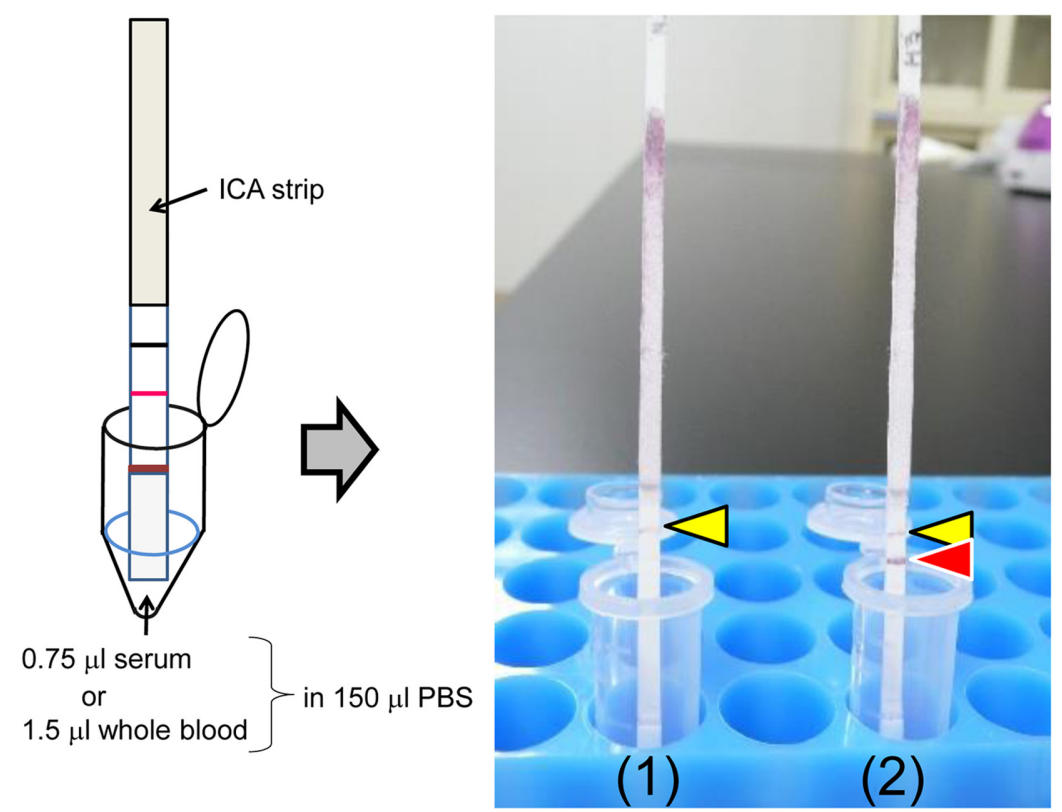

Fig. 1. Detection method and scheme of the immunochromatographic assay (ICA) strip. (A) Structure of the ICA. Antigens and anti-rabbit IgG antibodies were placed at the test line and control line, respectively. The ICA strip consisted of 4 membrane pads: a sample pad, conjugate pad, nitrocellulose membrane, and absorbent pad. The conjugate pad contained the anti-rat IgG antibodycolloidal gold conjugate. (B) Detection method. Serum $(0.75 \mu 1)$ and whole blood $(1.5 \mu 1)$ were diluted with $150 \mu \mathrm{l}$ of PBS and then placed in a microtube. The strip was dipped in the solution for $15 \mathrm{~min}$, and then the test (red arrow) and the control (yellow arrow) lines were examined visually. A sample for which only the control line appeared was regarded as negative (1), and a sample for which both test and control lines appeared was regarded as positive (2). 


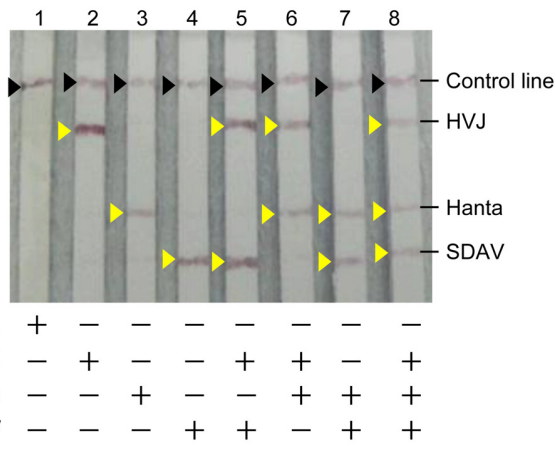

Fig. 2. Multiplex immunochromatographic assay (ICA) using diluted antibody-positive serum. Uninfected (control) serum and each positive serum were diluted with $150 \mu 1$ of PBS. Lanes 1 to $4,0.75 \mu 1$ of serum in PBS; lanes 5 to 8 , PBS containing $0.35-\mu 1$ portions of either 2 or 3 antibody-positive sera.

A
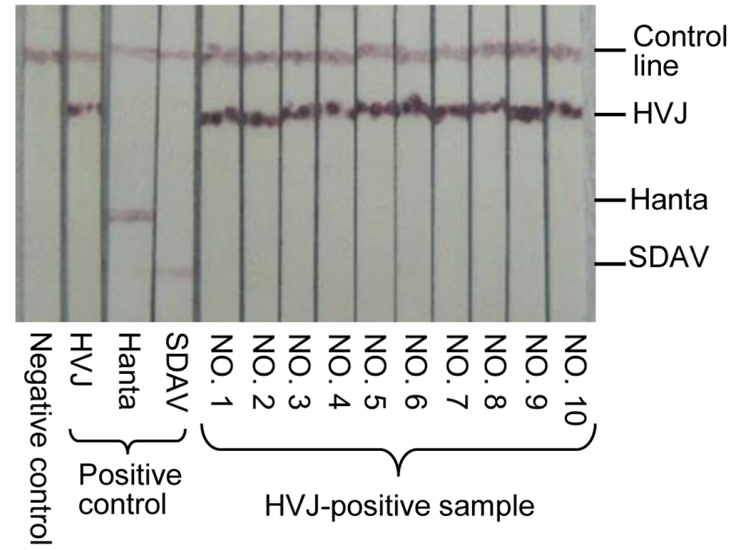

C
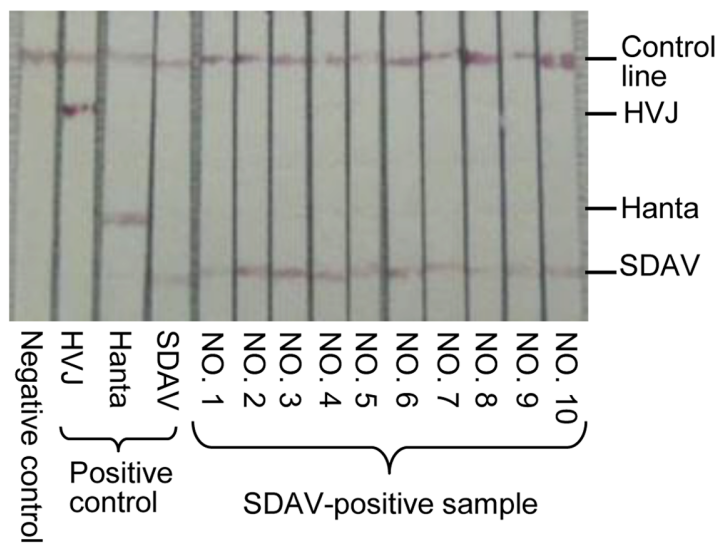

Table 1. Calculation of the sensitivity and specificity of the multiplex immunochromatographic assay (ICA)

\begin{tabular}{ccc}
\hline Infectious diseases & Sensitivity $^{\mathrm{a})}$ & Specificity $^{\mathrm{b})}$ \\
\hline HVJ & $10 / 10(100 \%)$ & $52 / 52(100 \%)$ \\
Hanta & $10 / 10(100 \%)$ & $52 / 52(100 \%)$ \\
SDAV & $26 / 32(81 \%)$ & $30 / 30(100 \%)$ \\
\hline
\end{tabular}

a) Sensitivity = positive according to the multiplex ICA / positive according to ELISA and an immunofluorescent antibody assay. b) Specificity = negative according to the multiplex ICA / negative according to ELISA and an immunofluorescent antibody assay.

\section{B}
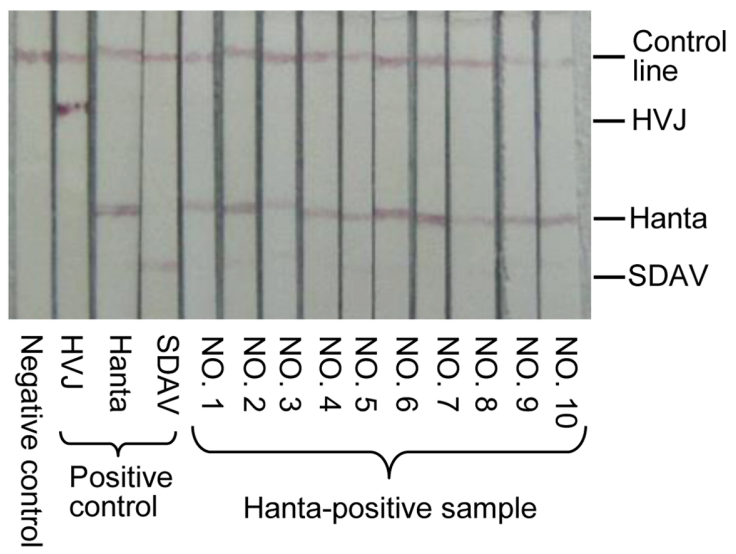

D
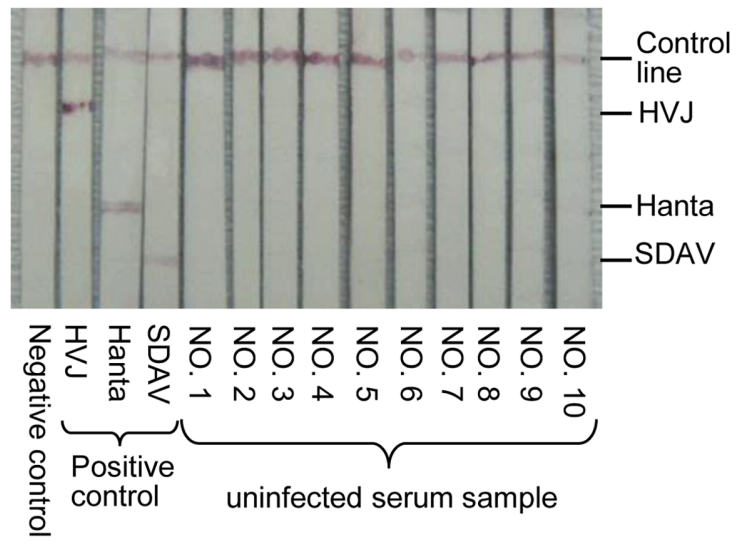

Fig. 3. Evaluation of the sensitivity and specificity of the multiplex immunochromatographic assay (ICA). Sera positive for antibodies to each infectious disease, HVJ (A), Hanta (B), and SDAV (C), diagnosed by using ELISA and an immunofluorescent antibody assay were used (10 samples per infectious disease). (D) Ten uninfected sera were used as negative serum samples. Serum $(0.75 \mu 1)$ was diluted with $150 \mu 1$ of PBS. 


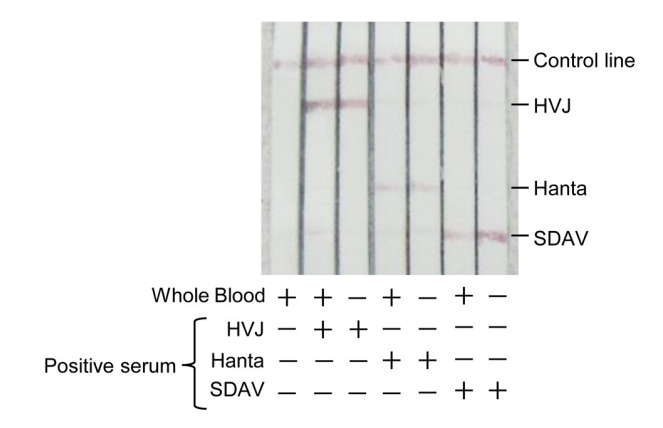

Fig. 4. Evaluation of the applicability of whole blood for multiplex immunochromatographic assay (ICA). Whole blood $(1.5 \mu \mathrm{l})$ was added to $150 \mu 1$ PBS with or without each serum $(0.75 \mu 1)$ positive for antibodies to HVJ, Hanta, and SDAV.

\section{Evaluation of the multiplex ICA using whole blood}

To investigate the applicability of whole blood dilution for the multiplex ICA, we compared the ICA results for diluted antibody-positive serum with the results for diluted antibody-positive sera mixed with whole blood. The multiplex ICA specifically detected antibodies to the HVJ, Hanta, and SDAV antigens in the presence of whole blood (Fig. 4). These observations suggest that the multiplex ICA can detect antibodies to HVJ, Hanta, and SDAV in whole blood without the need to remove RBCs from samples.

\section{Discussion}

Our multiplex ICA containing antigens for HVJ, Hanta, and SDAV specifically and simultaneously detected antibodies to the corresponding antigens using only a small amount of serum. In addition, it showed high levels of specificity and sensitivity among antibodypositive and uninfected serum samples. Moreover, it was applicable to diluted whole blood.

Monitoring of the microbiological status of rodents has been commonly carried out by examining sentinel animals that have been exposed to possibly contaminated soiled bedding for several weeks. However, some infectious agents, such as HVJ, in individually ventilated caging are not effectively transmitted through soiled-bedding transfer $[15,16]$. To solve this problem, methods for assessing exposed sentinel animals by surveying the exhaust air of individually ventilated cages have been reported $[15,17-20]$. If a pathogenic microbe is detected in animal rooms, sentinels and experimental animals must be examined to identify the sources of infection or sensitive hosts. Since the number of strains maintained is currently increasing, a limited number of animals tends to be used to maintain each strain. This situation prevents sufficient numbers of animals of each strain from being used for testing. Moreover, assessment of microbial status without euthanizing animals, including sentinels, is regarded as important from the viewpoint of the 3Rs. Therefore, experimental animals need to be evaluated without euthanizing them.

Although PCR-based methods are used to detect genomes of pathogens in feces of rats for diagnosis of infectious diseases without euthanizing rats [1,5], PCRbased methods are not applicable in cases of pathogens that lack fecal shedding of antigens, such as HVJ, or when the period of antigen shedding in feces is very short. In these situations, serologic diagnosis is more effective for biologic monitoring purposes. A multiplex microbead immunoassay has been shown to be useful for serologically diagnosing infectious diseases without euthanizing rats $[2-4,6,21,22]$. Recently, the use of bioluminescence imaging for in vivo monitoring of infectious diseases has also been reported [23]. However, for in-house evaluations, these methods are impractical because they require an expensive, dedicated analyzer. On the other hand, the multiplex ICA is useful for inhouse monitoring because it enables simple, simultaneous, and specific detection by directly placing the ICA strip into a microtube containing a small amount of serum or blood diluted with PBS (Fig. 1B).

ELISA has been mainly used for serological diagnosis in laboratory rats. In the current study, we used serum samples found to be positive for antibodies against HVJ, Hanta, and SDAV by ELISA and an immunofluorescent antibody assay to evaluate the sensitivity and specificity of our multiplex ICA. The rate of detection of the specific antibody to SDAV was $81 \%$ (26 of 32 samples; Fig. $3 \mathrm{~A}$ and Table 1). This result indicated that ICA was less sensitive than ELISA for detection of SDAV. Further studies including correlation and comparison analyses of ELISA OD values and detection by ICA are needed to determine whether ICA-negative and ELISA-positive results are due to the low titer of specific antibodies to SDAV. Recently, a multiplex microbead immunoassay has been used for diagnosis of infectious diseases [2-4, 6]. It was reported that a multiplex microbead immunoassay is as sensitive as and more specific than MHV ELISA for screening of antibodies to SDAV [6]. This suggests that ICA is also less sensitive than a multiplex microbead immunoassay for detection of SDAV. In comparison, the rate of detection of specific antibodies to Hanta and HVJ was $100 \%$ (10 of 10 samples) for both pathogens (Figs. 3A and B, Table 1). The sensitivity of Hanta in our multiplex ICA conforms with the results of our study showing that the overall sensitivity and specificity of the single ICA of Hanta in sera from 192 urban 
rats and 123 laboratory rats were $99.3 \%$ and $100 \%$ when compared with ELISA and IFA, respectively [8]. It has been shown that a recombinant antigen (HS103) for Hanta, which was used in this study, cross-reacted with Thailand virus, Hantaan virus, and Dobrava/Belgrade virus, which are also Murinae rodent-derived hemorrhagic fever with renal syndrome-related hantaviruses [8]. These results suggest that our multiplex ICA detects antibodies against the Thailand virus, Hantaan virus, and Dobrava/Belgrade virus. However, many more positive serum samples need to be analyzed to precisely evaluate the sensitivity of ICA for HVJ. Conversely, ICA did not produce nonspecific reactions in any of the 52 positive sera (Figs. 3A-C and Table 1). In addition, 10 uninfected control sera did not show any bands except for the internal positive control for each test (Fig. 3D and Table 1). These results indicate that the multiplex ICA has high specificity for HVJ, Hanta, and SDAV.

According to recommendations from the Federation of European Laboratory Animal Science Associations (FELASA), health monitoring programs in laboratory animal facilities should include at least 11 pathogens [24]. In the current study, our multiplex ICA specifically detected antibodies to 3 pathogens: HVJ, Hanta, and SDAV. Therefore, to use the multiplex ICA widely for routine serologic screening, it will need to identify antigens to several more infectious diseases than just these 3 agents. We previously reported an ICA that is a highly sensitive, rapid and simple diagnostic method for detecting $\operatorname{IgG}$ to Hanta in rat serum $[8,9,13]$. Although additional pathogens need to be included to adapt the ICA for microbiological monitoring, the format developed in the current study is an effective and rapid tool for evaluation of HVJ and SDAV or in the case of a disease outbreak due to one of these pathogens.

The multiplex ICA specifically detected antibodies to HVJ, Hanta, and SDAV antigens in the presence of whole blood (Fig. 4). This suggests that samples for the multiplex ICA do not require removal of RBCs. Furthermore, serum samples from dried blood on filter paper have been used widely for human and veterinary diagnostic tests $[25,26]$. Various microsampling devices for collecting blood have become available commercially. Additional studies to determine whether the multiplex ICA can be applied to dried-blood samples are needed to achieve practical use of this test modality.

The preparation of ICA strips is time-consuming and labor-intensive, and many laboratories may lack the necessary reagent and technical skill. However, ICA has many advantages exceeding these disadvantages. Since ICA strips can be kept at room temperature for at least 3 months (data not shown), nonrefrigerated transport of test strips should be possible. In addition, the cost to prepare ICA strips is low. In fact, ICA strips have been widely used to diagnose various infectious diseases by detecting antibodies against pathogens [27-31]. Commercial production of test strips might overcome these disadvantages.

This study showed that the multiplex ICA using three antigens, HVJ, Hanta, and MHV, could simultaneously and specifically detect antibodies to HVJ, Hanta, and SDAV in small quantities of serum or diluted blood. This suggests that the multiplex ICA has promise for future diagnostic applications in laboratory rats. Further work, such as serological tests using a larger number of samples from rats maintained in a variety of animal facilities and incorporating additional infectious agents, is needed to achieve practical use of the ICA.

\section{Acknowledgments}

This work was supported by a Grant-in-Aid for Science Research from the Japan Society for the Promotion of Science (15K07717).

\section{References}

1. Furukawa T, Furumoto K, Fujieda M, Okada E. Detection by PCR of the Tyzzer's disease organism (Clostridium piliforme) in feces. Exp Anim. 2002; 51: 513-516. [Medline] [CrossRef]

2. Khan IH, Kendall LV, Ziman M, Wong S, Mendoza S, Fahey J, et al. Simultaneous serodetection of 10 highly prevalent mouse infectious pathogens in a single reaction by multiplex analysis. Clin Diagn Lab Immunol. 2005; 12: 513-519. [Medline] [CrossRef]

3. Mani A, Ravindran R, Mannepalli S, Vang D, Luciw PA, Hogarth M, et al. Data mining strategies to improve multiplex microbead immunoassay tolerance in a mouse model of infectious diseases. PLoS One. 2015; 10: e0116262. [Medline] [CrossRef]

4. Ravindran R, Khan IH, Krishnan VV, Ziman M, Kendall LV, Frasier JM, et al. Validation of multiplex microbead immunoassay for simultaneous serodetection of multiple infectious agents in laboratory mouse. J Immunol Methods. 2010; 363: 51-59. [Medline] [CrossRef]

5. Smith GD, Solenberg PJ, Koenig MC, Brune KA, Fox N. Use of TaqMan reverse transcriptase-polymerase chain reaction analysis and serologic testing to eliminate an enzootic infection of mouse hepatitis virus. Comp Med. 2002; 52: 456-460. [Medline]

6. Kunita S, Kato K, Ishida M, Hagiwara K, Kameda S, Ishida T, et al. Simultaneous detection of antibodies to mouse hepatitis virus recombinant structural proteins by a microsphere-based multiplex fluorescence immunoassay. Clin Vaccine Immunol. 2011; 18: 758-766. [Medline] [CrossRef]

7. Tosa N, Ishida T, Yoshimatsu K, Hayashimoto N, Shiokawa $\mathrm{K}$, Takakura A, et al. Multiplex immunochromatographic assay for serologic diagnosis of major infectious diseases in laboratory mice. J Am Assoc Lab Anim Sci. 2019; 58: 790-795. [Medline] [CrossRef]

8. Amada T, Yoshimatsu K, Yasuda SP, Shimizu K, Koma T, Hayashimoto N, et al. Rapid, whole blood diagnostic test for detecting anti-hantavirus antibody in rats. J Virol Methods. 
2013; 193: 42-49. [Medline] [CrossRef]

9. Yoshimatsu K, Arikawa J. Serological diagnosis with recombinant $\mathrm{N}$ antigen for hantavirus infection. Virus Res. 2014; 187: 77-83. [Medline] [CrossRef]

10. Goto K, Hayashimoto N, Ishida T, Takakura A, Kagiyama N. First trial in the developmental phase of the "performance evaluation program" based on the ICLAS animal quality network program: self-assessment of microbiological monitoring methods using test samples supplied by ICLAS. Exp Anim. 2009; 58: 47-52. [Medline] [CrossRef]

11. Hayashimoto N, Morita H, Ishida T, Yasuda M, Kameda S, Uchida R, et al. Current microbiological status of laboratory mice and rats in experimental facilities in Japan. Exp Anim. 2013; 62: 41-48. [Medline] [CrossRef]

12. Kagiyama N, Takakura A, Terada E, Sakurai Y, Suzuki H. Studies on the development of an ELISA kit for microbiological monitoring. 2. Improvement of the prototype ELISA kit with special references to mouse hepatitis virus antigen. Jikken Dobutsu. 1990; 39: 97-102. [Medline]

13. Amada T, Yoshimatsu K, Koma T, Shimizu K, Gamage CD, Shiokawa K, et al. Development of an immunochromatography strip test based on truncated nucleocapsid antigens of three representative hantaviruses. Virol J. 2014; 11: 87. [Medline] [CrossRef]

14. Institute for Laboratory Animal Research. Guide for the care and use of laboratory animals, 8th ed. Washington DC: National Academies Press; 2011.

15. Compton SR, Homberger FR, Paturzo FX, Clark JM. Efficacy of three microbiological monitoring methods in a ventilated cage rack. Comp Med. 2004; 54: 382-392. [Medline]

16. de Bruin WC, van de Ven EM, Hooijmans CR. Efficacy of soiled bedding transfer for transmission of mouse and rat infections to sentinels: a systematic review. PLoS One. 2016; 11: e0158410. [Medline] [CrossRef]

17. Brielmeier M, Mahabir E, Needham JR, Lengger C, Wilhelm $\mathrm{P}$, Schmidt J. Microbiological monitoring of laboratory mice and biocontainment in individually ventilated cages: a field study. Lab Anim. 2006; 40: 247-260. [Medline] [CrossRef]

18. Miller M, Brielmeier M. Environmental samples make soiled bedding sentinels dispensable for hygienic monitoring of IVC-reared mouse colonies. Lab Anim. 2018; 52: 233-239. [Medline] [CrossRef]

19. Miller M, Ritter B, Zorn J, Brielmeier M. Exhaust air dust monitoring is superior to soiled bedding sentinels for the detection of pasteurella pneumotropica in individually ventilated cage systems. J Am Assoc Lab Anim Sci. 2016; 55: 775-781. [Medline]

20. Zorn J, Ritter B, Miller M, Kraus M, Northrup E, Brielmeier M. Murine norovirus detection in the exhaust air of IVCs is more sensitive than serological analysis of soiled bedding sentinels. Lab Anim. 2017; 51: 301-310. [Medline] [CrossRef]
21. Feng S, Kendall LV, Hodzic E, Wong S, Lorenzana E, Freet K, et al. Recombinant Helicobacter bilis protein P167 for mouse serodiagnosis in a multiplex microbead assay. Clin Diagn Lab Immunol. 2004; 11: 1094-1099. [Medline] [CrossRef]

22. Hsu CC, Wobus CE, Steffen EK, Riley LK, Livingston RS. Development of a microsphere-based serologic multiplexed fluorescent immunoassay and a reverse transcriptase PCR assay to detect murine norovirus 1 infection in mice. Clin Diagn Lab Immunol. 2005; 12: 1145-1151. [Medline] [CrossRef]

23. Avci P, Karimi M, Sadasivam M, Antunes-Melo WC, Carrasco E, Hamblin MR. In-vivo monitoring of infectious diseases in living animals using bioluminescence imaging. Virulence. 2018; 9: 28-63. [Medline] [CrossRef]

24. Mähler Convenor M, Berard M, Feinstein R, Gallagher A, Illgen-Wilcke B, Pritchett-Corning K, et al. FELASA working group on revision of guidelines for health monitoring of rodents and rabbits. FELASA recommendations for the health monitoring of mouse, rat, hamster, guinea pig and rabbit colonies in breeding and experimental units. Lab Anim. 2014; 48: 178-192. [Medline] [CrossRef]

25. Curry PS, Ribble C, Sears WC, Orsel K, Hutchins W, Godson $\mathrm{D}$, et al. Blood collected on filter paper for wildlife serology: evaluating storage and temperature challenges of field collections. J Wildl Dis. 2014; 50: 308-321. [Medline] [CrossRef]

26. Geers LM, Cohen D, Wehkamp LM, van Hateren K, Koster RA, Fedorenko OY, et al. Dried blood spot analysis for therapeutic drug monitoring of clozapine. J Clin Psychiatry. 2017; 78: e1211-e1218. [Medline] [CrossRef]

27. Chong YM, Tan XH, Hooi PS, Lee LM, Sam IC, Chan YF. Evaluation of rapid influenza diagnostic tests for influenza A and B in the tropics. J Med Virol. 2019; 91: 1562-1565. [Medline] [CrossRef]

28. Li Q, Wang L, Sun Y, Liu J, Ma F, Yang J, et al. Evaluation of an immunochromatographic strip for detection of avian avulavirus 1 (Newcastle disease virus). J Vet Diagn Invest. 2019; 31: 475-480. [Medline] [CrossRef]

29. Mahinc C, Flori P, Delaunay E, Guillerme C, Charaoui S, Raberin $\mathrm{H}$, et al. Evaluation of a New Immunochromatography Technology Test (LDBio diagnostics) to detect toxoplasma IgG and IgM: comparison with the routine architect technique. J Clin Microbiol. 2017; 55: 3395-3404. [Medline] [CrossRef]

30. Paulini I, Siqueira-Silva J, Thomaz L, Rocha L, Harsi C, Bellei $\mathrm{N}$, et al. Development of a prototype immunochromatographic test for rapid diagnosis of respiratory adenovirus infection. Braz J Infect Dis. 2017; 21: 500-506. [Medline] [CrossRef]

31. Xu R, Zhao DY, Lu K, Hong Y, Li H, Lin JJ, et al. [Development of colloidal gold immunochromatography assay strip for schistosomiasis diagnosis in domestic animals]. Zhongguo Xue Xi Chong Bing Fang Zhi Za Zhi. 2015; 27: 474-478. [Medline] 